\title{
Introducing the genetic improvement of olive trees in Morocco by crossbreeding
}

\author{
EL Oualkadi A ${ }^{1}$, Hajjaj B ${ }^{1}$, El Hereich A ${ }^{2}$, Sedra My H ${ }^{2}$
}

\author{
${ }^{1}$ INRA- Regional Agricultural Research Center of Tangier, Morocco \\ ${ }^{2}$ INRA -Regional Agricultural Research Center of Marrakesh, Morocco \\ Corresponding author: ai.oualkadi@gmail.com
}

\begin{abstract}
The genetic improvement of the olive tree by crossing is a new work in Morocco and even in the olive countries of the Mediterranean. The objective of this work is to improve the performance of our selected Moroccan variety (Haouzia) by crossbreeding with European variety (Frontoio) with high-performance traits relating to the quality, quantity of fruit, oil and resistance to verticilliose. The result show Rate of fruit set is $63 \%$ as well as the fruiting rate of $50 \%$.
\end{abstract}

Keywords-Olive tree, Haouzia, Frontoio, genetic improvement, Morocco.

\section{INTRODUCTION}

Olive tree is the main fruit species in most countries of the Mediterranean basin, both in terms of the number of trees grown and socioeconomic importance of its cultivation and its environmental role. In Morocco, this crop occupies a prominent place in the economic and social life of rural population. In Fact, olive tree plays an important role in helping to support most people in certain regions of the country where it is a main source of income. Genetic improvement of the olive tree by crossing is an essential way for the completion of a new and efficient genetic material. It is an alternative that preserves certain intrinsic traits to cultivars that have already been proven to adapt to environmental conditions or have intrinsic qualities that should be retained or to improve. In cultivated olive trees, knowledge of the genes involved in the variability of agronomic traits should make the best use of this variability for the selection of new varieties in response to new societal demands and environmental change. Disease resistance is one of the most important aspects currently studied. The olive tree is attacked by several fungal diseases such as the peacock's eye (Cycloconium oleaginum), rotting roots and wood (Armillariella mellea)...etc. However, the most important fungal disease is the Verticillium wilt, which can lead to the death of trees, and thus a reduction in production. This disease is found in several Mediterranean countries [1]. In Morocco, the disease was first noted in Meknes region [2]. Since then, it spread intensively in Morocco and is now widespread in the main growth area of the olive tree [3]. Control of Verticillium dahliae is difficult due to the absence of host specificity and extreme variability of the pathogen. Variety resistance offers the most effective and cost-effective ways to reduce the impact of the disease. Despite the economic importance of this plant, the genetic determinism of traits of agronomic interest is very poorly known. Unlike other species such as the genus Vitis, where only a few genomic regions involved in phenotypic variability have been mapped for major genes [4] and QTLs [5]. Seed germinability strongly depends on the parents used for crossing: germination rates can be very low for some breeding combinations [6]; [7]. There have been few crossbreeding programs for olive in different areas. Some of them are recent, while others have already reached their objectives, resulting in the release of new olive cultivars. Recently, resistance to pests and diseases, tree vigour and growth and grafting compatibility were considered as selective criteria [8]; [9]; [10], associated to indexing for viral infection [11]. Regional Agricultural Research Center of Marrakech has a wide range of genetic resources, including the global olive collection and the controlled croaking genotypes, as well as the molecular characterization of these genetics resource are necessary in order to select high-performance genotypes. The search for QTL related to the resistance to Verticiliosis will allow assistance in the selection of high-performance genotypes for these characters. In this work we crossed two varieties "Haouiza and Frontoio" for the search for QTL related to the resistance to Verticillium wilt which will allow assistance in the selection of high-performance genotypes for these traits.

\section{MATERIAL AND METHODS}

\section{Vegetal material}

We used too varieties of olive: Haouzia variety which is a new variety selected by INRA Marrakech productive and not 
altering, early maturity, average vigor, the tree has a rate of $50 \%-60 \%$ perfect flowers, its olive production is $60 \mathrm{Kg}$ per tree and sensitive to Verticillium wilt. Frontoio variety which it is of Italian origin enters in production early and its high productivity improves in the presence of appropriate pollinator, its oil yield between $20-22 \%$, high quality oil organoleptics, its production is $11.28 \mathrm{Kg}$ per tree, more or less self-fertile, good resistance to cold and drought and tolerance to Verticillium dahliae.

\section{Crossover and technical plan}

The cross is made between "Frontoio" and "Haouzia" whose "frontoio" is the female variety and the other is the male in 2013 at laboratory of genetic improvement of plant, Regional Agricultural Research Center of Marrakesh, Morocco. On the trees of the variety "Haouzia" chosen as pollinators, is carried out the bagging of twigs in order to collect pollen intended for the pollination of "Frontoio". To avoid any external pollination, bags previously put on the trees of "Frontoio" before opening the white button stage flowers. If there are flowers already open, unexploded anthers (castration) are eliminated, while those that are not dehiscent the entire flower is eliminated, with a daily passage for castration. After the anthesis of the pollen bags of the variety "Haouzia", bags are removed and their contents are sifted to rid pollen of unwanted parts (petals, sepals...) [12]; [13]. Finally, directed pollination is done using a brush.

\section{Rate of fruit set and fruiting rate}

After fecundation, ovaries begin to develop to young fruits that will continue their growth until the mature fruit is formed, these are harvested manually and then collected in bags. Afterwards, they are pitted at the end of obtaining nuclei and then they are rinsed and dried in the shade. After fertilization, flowers set are counted to calculate the rate of fruit set. Directly after fruit set, Urea $46 \%$ is sprayed every 15 days to promote fruit growth and reduce the percentage of falls. Rate of fruit set and Fruiting rate are calculated using the formulas: Rate of fruit set $=$ [Number of flower set / Total number of Flower] x 100. Fruiting rate $=[$ Number of fruit $/$ Total number of flowers $]$ x 100 .

Genetic characterization of the descendants of the cross Haouzia and Frontoio by the molecular biology technique

\section{Genomic DNA extraction}

The extraction begins by grinding the freeze-dried leaves of each sample. It consists of drying the leaves, already wiped with cotton, cold by a freeze-drying system which must be set to a temperature that varies between -80 and $83^{\circ} \mathrm{C}$, and they are left three days before recovering them. Then, $40 \mathrm{mg}$ of this grind is put in a $2 \mathrm{ml}$ Eppendorf tube. The addition of the nuclear lyse solution to this grind allows the dispersal of lipid bilayers of membranes, and the denaturation of proteins, especially those associated with DNA. The mixture is incubated in water bath. The next step is to precipitate the proteins, which allows the isolation of the DNA by simple centrifugation. The addition of isopropanol to the isolated supernatant allows the DNA to be precipitated and collected in a nerve after centrifugation. The removal of traces of any contaminants that can influence the purity of DNA is ensured by ethanol. Finally, the DNA is solubilized by adding the rehydration solution.

\section{Agarose gel electrophoresis 1\%}

To test the quality of the extracted DNA, an electrophoretic migration was performed on a $1 \%$ agarose gel (1 $\mathrm{g}$ agarose in $100 \mathrm{ml}$ of TBE 1-1). The visualization of the gel is done through the addition of Ethedium Bromure $(10 \mathrm{mg} / \mathrm{ml})$, which intersects between the nitrogen bases of the DNA strands and gives an orange-red inflorescence under ultraviolet radiation. After polymerization of the gel, 51 of DNA was mixed with 31 of agarose blue, then deposited in each well. To collect the size of the strips, the molecular marker (1 kb DNA Ladder) was deposited in another well. In an electrophoretic cell filled with TBE 1,000 , the DNA migrates under a voltage of 160 Volts for 35 minutes.

\section{RESULT AND DISCUSSION}

\section{Haouzia and Frantoio crossing}

Obtained results from this cross are well representative, 577 of knotted flowers yielded 454 fruits. The Rate of fruit set is $63 \%$ as well as the fruiting rate of $50 \%$. As of $10 / 11 / 2012$, we harvested a total of 136 fruits that remained among the 454 fruits in July 2013. These fruits are then pitted and the olive stone are stored and dormant for a month. After one month, these olive stone will be germinated in petri dishes. Once sprouted these seeds will be transplanted into plastic bags and will be put in environmental conditions in the laboratory until the first leaves are developed. The rate of fruit set and fruiting rate we obtained for this crossing are shown in table 1 . 


\begin{tabular}{ccccc}
\hline Number of Flower bagged & Number of Flower set & Number of fruit & Rate of fruit set (\%) & Rate of fruiting (\%) \\
\hline 905 & 577 & 454 & 63 & 50 \\
\hline
\end{tabular}

\section{Genomic DNA extraction}

We carried out genomic extraction using the $\mathrm{CTAB}$ extraction technique, to show the quality of our DNA extracted at the level of a $1 \%$ agarose gel. Thus DNA was quantified using the spectrophotometer (Eppendorf Biophotometer).

\section{Checking the quality of DNA extracted}

The quality verification of genomic DNA extracted from the various samples studied was carried out on $1 \%$ agarose gel. Fig. 4, fig.5 and fig.6 show results of extraction.
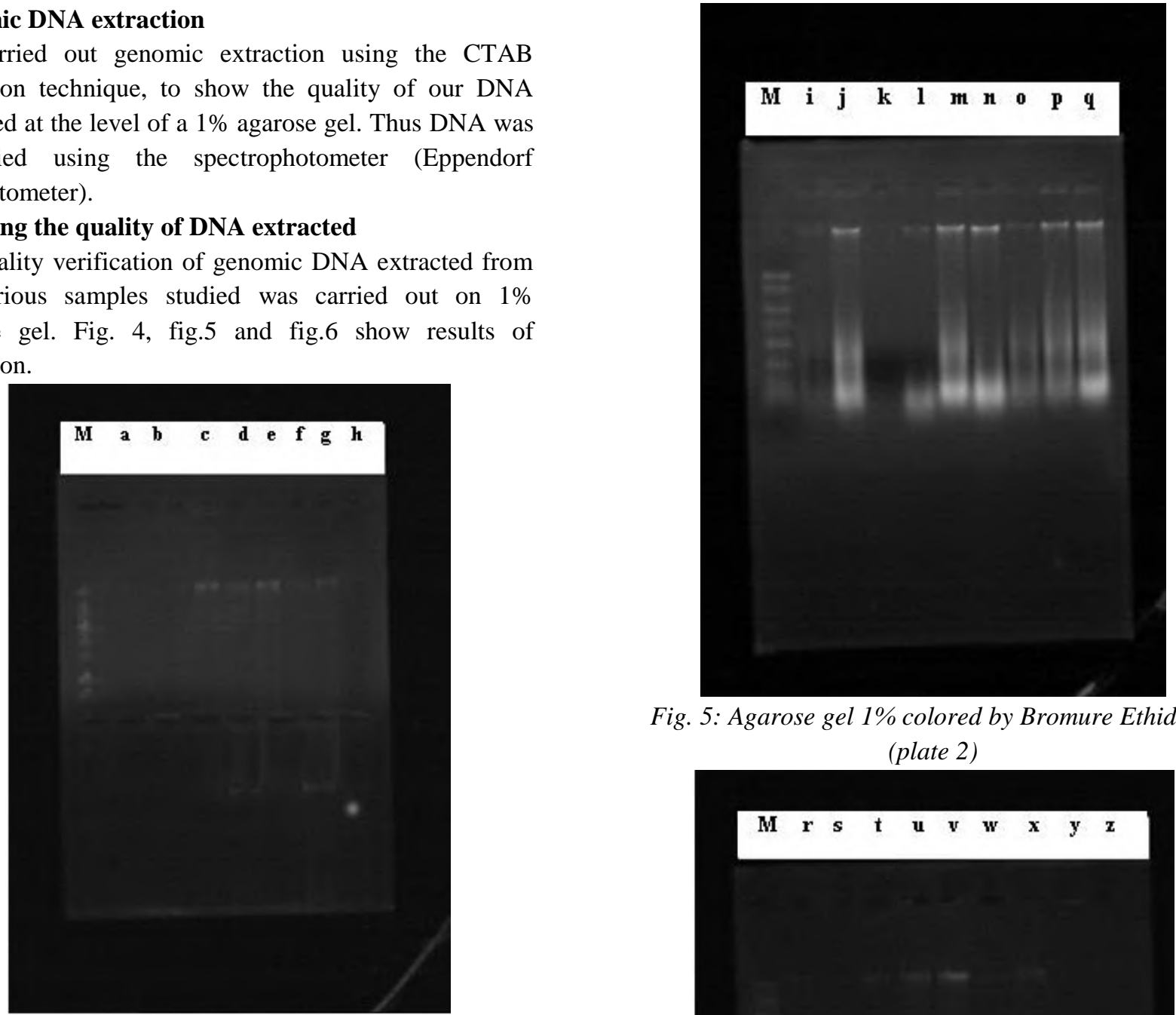

Fig. 5: Agarose gel 1\% colored by Bromure Ethidium (plate 2)

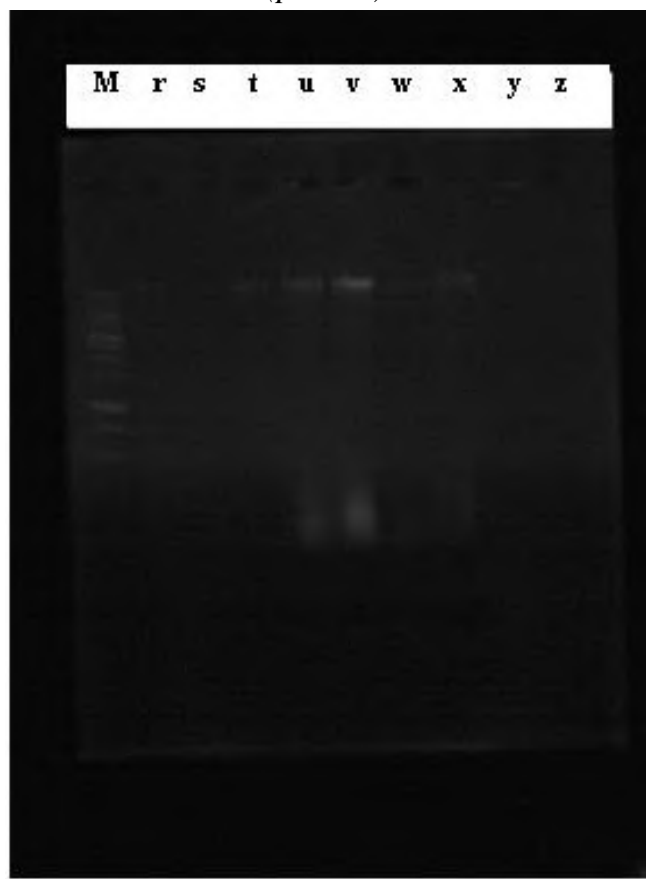

Fig. 6: Agarose gel 1\% colored by Bromure Ethidium (plate 3)

Table 2: Intensity of DNA bands visualized on agarose gel 1\% depending on the varieties 
Plaque 1:

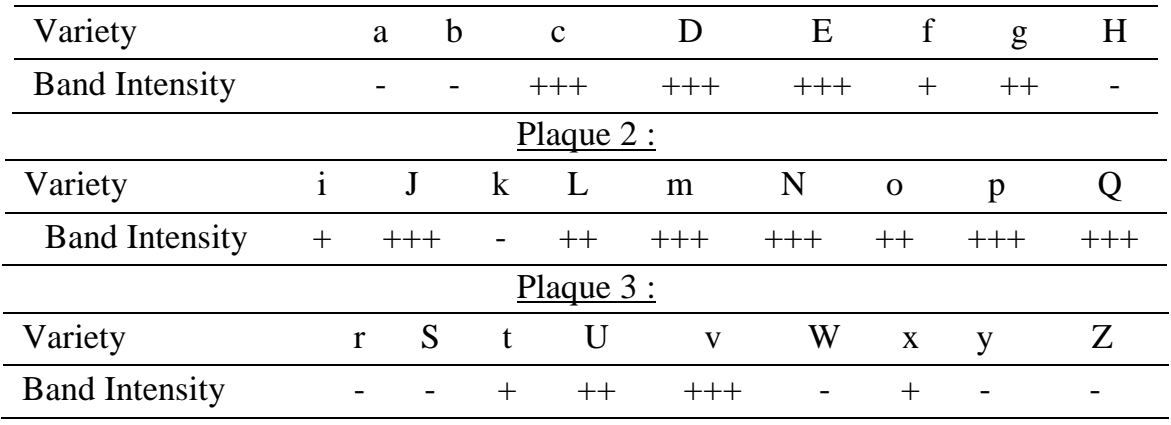

The $1 \%$ agarose gel migration achieved to qualify and quantify the DNA obtained from the extraction of olive leaves by the method (CTAB), showed clearly visible bands on agarose gel in most of the individuals studied, indicating that our DNA extract is pretty good quality to good with little drag that shows there is no DNA degradation.

Checking the amount of DNA extracted

After measuring the optical density of the different olive genotypes at 260 and $280 \mathrm{~nm}$, results are shown in Table

*Table 3: Measurements of the optical density of different olive tree genotypes

\begin{tabular}{|c|c|c|c|c|}
\hline Sample & DO to $260 \mathrm{~nm}$ & DO to $280 \mathrm{~nm}$ & Concentration in $\mu \mathrm{g} / \mathrm{ml}$ & Report DO (260/280nm) \\
\hline $\mathrm{a}$ & 0.6 & 0.8 & 120 & 0.75 \\
\hline $\mathrm{b}$ & 0.5 & 0.8 & 100 & 0.625 \\
\hline $\mathrm{c}$ & 1.50 & 0.90 & 300 & 1.66 \\
\hline $\mathrm{d}$ & 1.2 & 0.78 & 240 & 1.53 \\
\hline $\mathrm{e}$ & 1.65 & 0.85 & 330 & 1.94 \\
\hline $\mathrm{f}$ & 1 & 0.5 & 200 & 2 \\
\hline $\mathrm{g}$ & 1.3 & 0.77 & 260 & 1.68 \\
\hline $\mathrm{h}$ & 0.5 & 0.7 & 100 & 0.71 \\
\hline $\mathrm{i}$ & 1.62 & 0.89 & 324 & 1.82 \\
\hline $\mathrm{j}$ & 1.7 & 0.7 & 340 & 2.4 \\
\hline $\mathrm{k}$ & 1.4 & 0.76 & 280 & 1.84 \\
\hline 1 & 1.65 & 0.89 & 330 & 1.85 \\
\hline $\mathrm{m}$ & 1.81 & 0.77 & 362 & 2.35 \\
\hline $\mathrm{n}$ & 1.77 & 0.81 & 354 & 2.18 \\
\hline o & 1.6 & 0.8 & 320 & 2 \\
\hline $\mathrm{p}$ & 1.84 & 0.86 & 368 & 2.25 \\
\hline$q$ & 1.47 & 0.72 & 294 & 2.28 \\
\hline $\mathrm{r}$ & 0.4 & 0.9 & 80 & 0.44 \\
\hline $\mathrm{s}$ & 0.48 & 0.78 & 96 & 0.61 \\
\hline $\mathrm{t}$ & 0.98 & 0.79 & 196 & 1.24 \\
\hline $\mathrm{u}$ & 1.02 & 0.68 & 204 & 1.5 \\
\hline V & 1.21 & 0.71 & 242 & 1.70 \\
\hline w & 0.3 & 0.90 & 60 & 0.33 \\
\hline $\mathrm{x}$ & 1.08 & 0.81 & 216 & 1.33 \\
\hline $\mathrm{y}$ & 0.35 & 0.88 & 70 & 0.39 \\
\hline z & 0.28 & 0.7 & 56 & 0.4 \\
\hline
\end{tabular}

IV. CONCLUSION
3. Result show that the ratio between Do at $260 \mathrm{~nm}$ and Do at $280 \mathrm{~nm}$ of our extracted DNA solutions which varies between 2 and 0.33 , this result allowed us to conclude that our DNA extracted are clean and of good quality and therefore good family. (Annex 4). From the amount of DNA extracted, DNA dilutions must be made for amplification reactions (PCR). 
In conclusion, the obtained results show that the crossing with Frontoio and Haouizia generated $63 \%$ of Rate of fruit set. Stratification treatment and the female parent clearly influenced olive seed germination and seedling emergence. Early seedling growth is also affected by the female. An initial verification of the first descendants of this cross showed the good quality of the DNA of these descendants. Subsequent work continuing to crossbreed to enrich the list of descendants, and genetic analyses will then be carried out on these descendants for the search for molecular markers related to resistance to Verticillium wilt.

\section{ACKNOWLEDGMENT}

The authors are grateful to all technicians of INRA Tassaout, Marrakech research station for providing necessary facilities for conducting this research work.

\section{REFERENCES}

[1] Tosi L, Zazzerini A (1998). An epidemiological study on Verticillium wilt of olive in central Italy. Olivae 71: 5055.

[2] Serrhini, M.N., 1992. Les maladies cryptogamiques importantes sur l'olivier au Maroc. Séminaire Sur Le contrôle Des Plantes D'olivier: Direction De La protection Des Végétaux, Contrôle Technique Et répression Des Fraudes, 1992. Rabat, Morocco

[3] Sedra, My. H., H. Laouane and H.B. Lazrek, 2002. Mise en évidence de la présence des toxines de Verticillium dahliae, agent causal de la verticilliose de l'olivier. Alawamia, 105: 85-93

[4] Fernandez MP, Nunez Y, Ponz F et al (2008) Characterization of sequence polymorphisms from microsatellite flanking regions in Vitis spp. Molecular Breeding 22: 455-465.

[5] Doligez A, Adam-Blondon AF, Cipriani G, Gaspero GDi, Laucou V, Merdinoglu D, Meredith CP, Riaz S, Roux C, This P (2006) An integrated SSR map of grapevine based on five mapping populations. Theoretical and Applied Genetics 113: 369-382.

[6] Bini G y Bellini E, 1975. Influenza dei genitori sulla facolta germinativa dei semi. Ricerche sull'olivo. Rivista della Ortoflorofrutticoltura Italiana 59: 371-384.

[7] Pritsa, T.S., D.G. Voyiatzis, C.J. Voyiatzis, and M.S. Sotitiriou. 2003. Evaluation of vegetative traits and their relation to time to first flowering of olive seedlings. Aust. J. Agr. Res. 54:371-376.

[8] SERRANO J.F., LEITÃO F., POTES M.F., SERRANO M.C., CLARA M.I., AMARAL L., 1999 - Preliminary observations on earliness of flowering and fructification of selected clones of Olea europaea L. - Acta Horticulturae, 474: 167-169.

[9] LORETI F., GUERRIERO R., TRIOLO E., VITAGLIANO C., 1993 - Proposta di metodo per la selezione clonale e sanitaria in olivicoltura. - Olivae, 47: 60-66.

[10] FIORINO P., 1999. Miglioramento genetico in olivo (Olea europaea L.). - Proceedings Seminario internazionale sulle 'Innovazioni scientifiche e loro applicazioni in olivicoltura ed in elaiotecnica. Miglioramento delle risorse genetiche'. Firenze, 10-12 March, pp. 1-24.

[11] Saponari M., Alkowni R., Driouech N., Hassan M., Grieco F., Pantaleo A., DI Terlizzi B., Digiaro M., Savino V., Martelli G.P., 2000 - Detection of olive-infec - ting viruses in the Mediterranean basin. - Acta Horticulturae, 586: 787 790.

[12] Griggs, W.H., Hartmann, H.T., Bradley, M.V., Iwakiri, B.T. and Whistler, J.E., 1975. Olive pollination in California. Calif. Agric. Exp. Sta Bull., 869: 50 pp.

[13] Musho U.-B. Contribution à l'étude de la biologie florale de l'olivier Olea europaea L.: mise en évidence de cas de stérilité mâle et recherche de pollinisateurs. USTLMontpellier. 1977 